\title{
Mazzaropi e a indústria de cinema do Brasil: a importância da comédia caipira para a cinematografia brasileira nos anos de 1950-1980
}

\section{Mazzaropi and Brazil's cinema industry: the importance of caipira comedy forbrazilian cinematography from 1950's to 1980's}

Thaís Valvano - Mestranda do Programa de Pós-Graduação em Ciências Sociais em Desenvolvimento, Agricultura e Sociedade da Universidade Federal Rural do Rio de Janeiro (CPDA/UFRRJ). Graduada em História pela Universidade Federal Fluminense (UFF).Email: thaisvalvano@gmail.com

\begin{abstract}
Resumo
Este trabalho propõe analisar a vida e obra do cineasta Amácio Mazzaropi, a partir das críticas especializadas sobre seus filmes. O intuito não é biográfico, à medida que propõe uma discussão maior sobre a sua obra e as impressões sobre o autor e personagem. A intenção é entender a infância do produtor e os caminhos que o levaram a criar sua produtora cinematográfica para identificar a importância do cineasta para a indústria brasileira de cinema e a representação da identidade caipira ante ao processo de urbanização à época. Finalmente, o artigo pretende responder algumas questões como a relação entre público e crítica; tradição e modernidade e a reprodução de identidades sociais.
\end{abstract}

\section{Palavras-chave}

Mazzaropi. Indústria cultural. Cultura caipira. Cinema.

\begin{abstract}
This work proposes to analyze of the Amácio Mazzaropi's life and cinematographic production, based on specialized criticism about his movies. It isn't a biographical study. The intention is to understand, through the producer's childhood, the ways that allowed him to build his own film company to identify the filmmaker importance to the brazilian industry of cinema and the representation of the caipira identity in the urbanization period. Finally, the article proposes to answer some questions as the relationship between public and critics; modernity and tradition and social identities reproduction.
\end{abstract}

\section{Keywords}

Mazzaropi. Cultural Industry. Caipira culture. Cinema. 


\section{INTRODUÇÃO}

Amácio Mazzaropi nasceu na capital do estado de São Paulo, mas foi no interior que passou praticamente toda a sua vida. Aos dois anos mudou-se com os pais para Taubaté, onde passou boa parte da infância. Acostuma ao cotidiano caipira, a vida e os costumes do interior, a volta a São Paulo aos sete anos foi um desafio, à medida que o menino teve que se adaptar novamente à cidade grande (MATOS, 2010). Anos mais tarde, tal conflito de adaptação seria fortemente representado em vários de seus filmes.

Sua infância e adolescência foram marcadas pela falta de recursos de sua família, seus pais não tinham muito dinheiro e quase sempre passavam por problemas financeiros. Em um deles, seu pai decidiu voltar à Taubaté para trabalhar na indústria têxtil da cidade, onde mais tarde Mazzaropi também trabalhou. Porém, desde criança o sonho de ser artista o dominava. Adorava ir ao teatro e os personagens de que mais gostava eram os caipiras, que faziam grande sucesso no teatro desde a sua infância, como ele declarou na entrevista que concedeu a revista "Veja" no ano de 1970,

$\mathrm{Na}$ adolescência, Mazzaropi começou a se envolver diretamente com o teatro. Ele mesmo dizia que trabalhava com teatro, "mas não como ator - eu pintava cenários. Aliás, eu amava a pintura, sempre amei a pintura. Pois bem, um belo dia "perdi” o pincel e resolvi seguir a carreira de ator" (MAZZAROPI, 1976).

Para entender os fatores que influenciaram as características de Mazzaropi como ator é importante considerar o contexto brasileiro, principalmente na cidade de São Paulo. Para tanto, é valido observar o trecho do texto de Cássio Santos Melo (2009), em que o autor caracteriza a capital paulista nos anos 20, argumentando que “a presença marcante do estado, como grande exportador e produtor de café, são aspectos que na virada do século XIX para o XX vão delineando novos contornos ao estado como um todo e à sua principal cidade, São Paulo" (MELO, 2009).

A partir desses fatores, pode-se considerar que a arte não estava alheia a essas questões, principalmente as peças apresentadas em circos e teatros populares, pois estas visavam ao diálogo com o público, que respondia à medida que se identificava com as histórias encenadas.

Essa relação de representação dos conflitos da sociedade nas peças de teatro é encontrada em quase todas as apresentações de Mazzaropi. O produtor saía para o interior contando piadas que muitas vezes eram sátiras que condiziam com a realidade do público. A sátira é um exemplo que representa bem a característica de Mazzaropi. Esse recurso se intensificou na medida em que o artista foi se familiarizando com as artes cênicas, principalmente depois que foi 
trabalhar com cinema. Desse modo, passou a satirizar, além dos sucessos dos filmes estrangeiros, os seus próprios colegas produtores que, segundo Mazzaropi, tinham um problema grande de não atentar para as necessidades do público.

Dizia ainda que seu sucesso advinha do trabalho que mostrava ao seu público. Segundo ele, seus filmes oferecem distração em forma de otimismo. "Eu represento os personagens da vida real. Não importa se um motorista de praça, um torcedor de futebol ou um padre. Eu documento muito mais a realidade do que construo" (MAZZAROPI, 1970). Essa é uma das principais peculiaridades de Mazzaropi, visto que o produtor primava por filmar em cenários reais, como uma praça na pequena cidade de São Luiz do Paraitinga ou o convento na cidade de Taubaté, a fim de criar um enredo o mais próximo possível da realidade.

Tais recursos cinematográficos não só possibilitaram um conhecimento melhor do tipo social que era representado no filme, como garantiu o sucesso de público. Mas antes de atingir tal sucesso como produtor, Mazzaropi já era um artista muito conhecido por seus programas no rádio e na televisão. Sua estreia no cinema se deu através de um teste para protagonizar o próximo filme da companhia de cinema Vera Cruz ${ }^{1}$ no ano de 1952. Sai da frente foi o seu primeiro filme, lançado no mesmo ano, e seguido por outros dois na mesma companhia. Em razão da crise na Vera Cruz, ele foi trabalhar na companhia Cinedistri, onde aprendeu os recursos essenciais para produzir um longa-metragem, além de atuar em mais três filmes. Assim, o artista estava cada vez mais perto de seu sonho.

\section{A PAM-FILMES E A CONSOLIDAÇÃO DA COMÉDIA CAIPIRA NO CINEMA BRASILEIRO}

Com o reconhecimento do público, o sucesso de suas piadas, capital inicial para o investimento em um sonho, Mazzaropi funda a sua própria produtora cinematográfica no ano de 1959 - a Produtora Amácio Mazzaropi - PAM filmes². Quando questionado sobre os motivos que o levaram a arriscar tão alto, dizia: "Eu via o cinema cheio de gente e meu bolso vazio. Tinha aprendido um pouco de cinema e resolvi fazer minhas próprias fitas. Afinal, minha empresa seria a única que teria o artista principal trabalhando de graça" (MATOS, 2010, p. 72).

Isso pode ser bem analisado na própria entrevista que Mazzaropi concedeu ao Movimento, em 1976. Ele defendia que caminhava rumo à consolidação de uma indústria cinematográfica brasileira:

\footnotetext{
1 Criada em 1949 pelos empresários Franco Zampari e Francisco Matarazzo Sobrinho: "Espelhada em Hollywood, fundaram a Companhia Cinematográfica Vera Cruz" (MATOS, 2010, p. 63).

2 Criada em 1958, passa a produzir os filmes de Mazzaropi, sendo que já no primeiro filme "Chofer da praça" atingiu grande sucesso de público.
} 
[...] tenho uma situação excepcional dentro do cinema brasileiro. Vejo isso pelo volume de fitas. A Pam Filmes, companhia distribuidora que é minha, tem filial no Rio de Janeiro, tem sede própria em Belo Horizonte, em Curitiba, Recife, Porto Alegre, e a matriz aqui em São Pauto, onde trabalham 80 pessoas. Estou inclusive adiantado em relação ao governo brasileiro, que pretende fazer um estúdio entre São Paulo e Rio (MAZZAROPI, 1976).

Esses dados não passavam despercebidos pelos críticos de cinema, inclusive existem fontes que mostram o interesse do governo da época nessas questões. Apesar de os anos de 1970 terem sido marcados por um forte controle político estatal representado pelo regime militar, não se pode esquecer que um dos principais objetivos do governo era fomentar o processo de industrialização nacional, incluindo a indústria cultural. Tal afirmação é vista no jornal Estado de São Paulo de 19 de outubro de 1971 (Figura 1), que cobriu o encontro entre Mazzaropi e o presidente Médici que discutiram sobre o fomento da indústria cinematográfica. Segundo o jornal, "o presidente Médici disse que dará todo o apoio ao cinema nacional para transformá-lo em indústria".

Figura 1 - Recorte do jornal Estado de São Paulo de 19 de outubro de 1971.

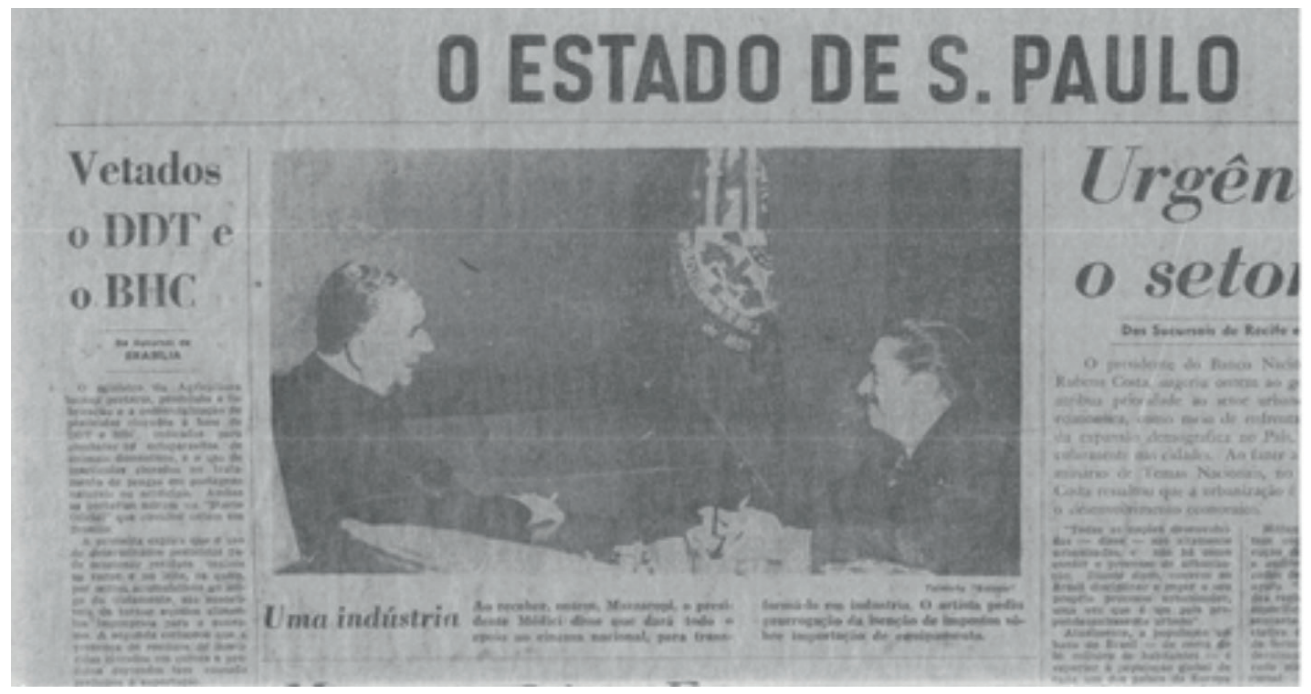

Fonte: Centro de Documentação e Pesquisa Histórica da Universidade de Taubaté (CDPH/UNITAU).

No entanto, o interesse do governo não era apenas de fomentar e enriquecer a cultura no Brasil, mas havia também forte interferência econômica nessa questão. Um exemplo disso foi o objetivo da reunião entre Mazzaropi e Médici. O produtor pretendia defender a isenção de impostos nas importações de equipamentos cinematográficos, pois tratava o cinema como negócio 
(MATOS, 2015, p. 105), tanto que criava artifícios para fugir das fraudes que ocorriam frequentemente.

O reconhecimento da importância de Mazzaropi na criação de uma indústria cinematográfica nacional parecia estar somente no encontro com o presidente e em alguns críticos que destacavam a popularidade do produtor. A crítica especializada, em geral, analisava os filmes mazzaropianos de forma pejorativa, muitas vezes chegando a desqualificá-los. Contudo, deve-se considerar o interesse político dos próprios jornais.

A maior parte dos relatos sobre os filmes de Mazzaropi está focada principalmente em seus lançamentos. A questão a se observar é que muitos críticos ressaltavam a falta de técnica, a precariedade de recursos e a repetição de enredos, ao mesmo tempo em que concordavam que se tratava de mais um sucesso de público. No entanto, existiam aqueles que ressaltavam que o grande número de espectadores nos filmes de Mazzaropi condizia com o subdesenvolvimento do Brasil, e que somente este condicionamento seria a explicação cabível para tal sucesso (LOYOLA, 1965).

Entretanto, salvo alguns críticos mais contestadores, como Ignácio de Loyola 3 , a maioria ressaltava a importância do público nos filmes de Mazzaropi. Também não era possível omitir essa questão, principalmente ao considerar a matéria de Paulo Moreira Leite para o jornal Folha de São Paulo do dia 8 de junho de 1977.

São duas mil pessoas, o trânsito está interrompido numa faixa da Avenida São João, o Largo Paissandu está agitado. Uma escola de samba, uma banda do interior as duas misturando batucada e marchinhas ao mesmo tempo. Motocicletas e viaturas do DSV, sirene, 5 soldados da PM e um sargento. Dois caminhões de uma estação de televisão, holofotes, fotógrafos. Então, com 45 minutos de atraso, o gálaxie preto estaciona junto à calçada do cine Art-Palácio, para a cerimônia de estreia do filme "Jecão... um fofoqueiro no céu" (MOREIRA, 1977).

Esses dados foram apresentados em 1977, quando Mazzaropi já havia consolidado a sua produtora que, a partir de sua fundação em 1959, passou a produzir um filme por ano e todos de relativo sucesso.

Os anos de 1970 foram fundamentais para a produção de Mazzaropi. Em todos os lançamentos era esperado um grande número de pessoas. O produtor determinava que fossem feitas em média 35 cópias, que eram distribuídas a um grande número de salas simultaneamente. Sabendo que o seu grande público estava em São Paulo, o produtor segurava as fitas durante um mês só no estado de São Paulo, para depois distribuir no Rio de Janeiro, Belo Horizonte, Curitiba, Recife e Porto Alegre.

Contista, romancista e jornalista brasileiro. Trabalhou no jornal Última Hora. 
Neste sentido, a crítica de Paulo Moreira Leite foi ainda mais enfática ao analisar a renda dos filmes mazzaropianos, especialmente o Jeca Macumbeiro (1974). Este filme atingiu um total de 530.306 espectadores em um ano de exibição - a maior bilheteria nacional do ano de 1975, atingindo 10,5 milhões de cruzeiros (MOREIRA, 1977). Esta afirmação sugere a demonstração da importância de Mazzaropi naquele momento, fato que, em certa medida, incomodava alguns críticos e chamava a atenção de outros tantos.

Mais um grande sucesso era esperado pelo público de Mazzaropi no ano de 1975. O produtor estava lançando a sua mais nova película intitulada O Jeca contra o Capeta. Ao analisar essa fita, alguns críticos diziam que ela foi inspirada no filme norte-americano O exorcista (1973), e que o produtor havia feito a sátira para aproveitar o sucesso que o filme estrangeiro fizera nas bilheterias do mundo todo. Contudo, acompanhando ou não o sucesso do filme, o que se pode afirmar é que a intensão de Mazzaropi não era reproduzir fielmente o enredo do filme hollywoodiano, mas sim satirizá-lo e garantir ao público muitas risadas.

Em um contexto mais geral, pode-se dizer que este filme agrega todas as peculiaridades dos filmes mazzaropianos, misturando comédia, questões sociais, violência e ingenuidade do caipira numa só produção. Tais fatores aparecem na discussão sobre a aprovação ou não da Lei do Divórcio, nas brigas intermináveis entre os homens do meio rural, nas graças do jeca e na suposta falta de malícia das pessoas do campo.

Neste aspecto, o filme pode ser considerado contestador, na medida em que se inicia com uma pesquisa de opinião. Os jornalistas saem às ruas querendo saber o que a população acha da Lei do Divórcio. Para isso, Mazzaropi filma a discussão em um cenário externo, como se reproduzisse, mais uma vez, o próprio cotidiano do seu público nas pequenas cidades. Desde o começo, a polêmica da aprovação da lei vai alterar as relações pessoais da cidadezinha. Alguns vão gostar da ideia e outros tantos vão ficar receosos, principalmente as mulheres, que ficam com medo de perder seus maridos.

A observação que se constrói a partir dos acontecimentos retratados no filme é de que a população do meio rural não estava preparada para a aprovação da lei do divórcio, pois somente a possibilidade de aprovação já alteraria as relações pessoais naquele meio. Neste sentido, além de expressar os problemas causados por tal notícia, Mazzaropi procura dialogar com os próprios personagens do filme, como o padre, por exemplo.

Assim, Mazzaropi cria um enredo sobre tradição e modernidade. Seus personagens ficam um tanto quanto atônitos com a modernização, que chegam a sentir falta dos antigos costumes. Isso é retratado de forma mais sistemática na 
conversa que o personagem Poluído tem com o padre da cidade. Inconformado com as mudanças que estavam ocorrendo no interior, o protagonista pergunta se o padre é a favor da lei do divórcio, confirmando a posição contrária da igreja e, consequentemente, a do caipira.

Entretanto, vale ressaltar que o filme foi produzido em 1975, e que a lei do divórcio só foi aprovada no Brasil em 1977, ou seja, havia uma discussão de âmbito nacional e o filme se posicionou contrário à nova lei. Além disso, legitimou a sua posição através de seus personagens, visto que os heróis da trama são contrários e os vilões a favor do divórcio.

A análise que Zulmira Tavares ${ }^{4}$ fez sobre a representação do divórcio no filme de Mazzaropi foi contundente:

$\mathrm{Na}$ verdade a qualidade de negra vilania emprestada ao divórcio deflagra toda a ação da estória; por exemplo o sedutor Camarão, ao tomar conhecimento da lei do divórcio, ri satanicamente e tenta logo em seguida violentar a mulher do próximo: um revólver dispara e Camarão morre (também por causa do divórcio, como se verá no fim); mente-se a respeito de uma duvidosa herança. A motivação? O divórcio. Porém, como tanto os divorcistas (os vilões) como os antidivorcistas (os heróis) agem da maneira mais fora de propósito possível na defesa de um ou de outro ponto de vista, a credibilidade de ambos os enfoques fica muito duvidosa (TAVARES, 1976).

Além disso, esta é mais uma característica de Mazzaropi explicitada no filme. Ele propõe uma questão e não a defende de forma determinada. Por mais que fique clara a sua posição sobre a questão do divórcio, por exemplo, ele a aborda de forma superficial e inserida numa gama de acontecimentos que ela acaba se manifestando apenas como uma consequência do que se desenrola na trama.

Portanto, é inviável realizar um estudo aprofundado sobre o filme Jeca contra o Capeta sem abordar os casos separadamente. Anteriormente, fiz uma breve contextualização do enredo para demonstrar como os acontecimentos se encadeiam. Portanto, torna-se necessário dar continuidade a essa explanação, porém de forma mais específica, de acordo com o interesse de cada personagem que vai usar a questão do divórcio para atingir seus objetivos ou para se defender.

O filme propõe a discussão de vários temas. É evidente que o divórcio é o tema central, mas, além dele, destacam-se a obsessão da fazendeira rica, a prisão do filho de seu Poluído, a aparição de um advogado de defesa um tanto suspeito, o encontro de Poluído com Jesus Cristo e a sátira ao filme O exorcista. Toda essa rede de elementos da trama é retratada simultaneamente. Portanto, neste artigo

4 É escritora, pesquisadora e professora de cinema, sendo integrante do conselho da Cinemateca Brasileira. 
me proponho a esquematizar tais questões não de acordo com o desenrolar do filme, mas de acordo com os casos abordados.

Aproveitando para ameaçar Poluído, Dionísia inventa para o caipira que viu Augusto matando Camarão e que o denunciaria caso o Jeca não se divorciasse para se casar com ela. Essa ameaça acontece logo no início do filme, e vai se estender por toda a história, fazendo com que Poluído, a fim de salvar o seu filho, fique cada vez mais envolvido na trama de Dionísia. O título do filme Jeca contra o Capeta tornase emblemático em uma cena em que o caipira tem um pesadelo e vê Dionísia ${ }^{5}$ se transformar em demônio. Por isso, o capeta não é força de outro mundo, ao contrário, é representado nas atitudes da fazendeira apaixonada pelo Jeca.

Outro fator importante no filme é a aparição de um advogado contratado por Dionísia, que inventa para o povo da cidade que o divórcio já foi aprovado, e que ele resolveria o processo de quem quisesse se divorciar. O problema é que a lei não tinha sido aprovada e o advogado se aproveitava da ignorância das pessoas para ganhar dinheiro através da criação de um falso processo de divórcio. Além disso, combinado com Dionísia, ele inventa uma herança que Poluído ganharia, para fazer com que ele e sua esposa assinassem o documento que, na verdade, seria o falso divórcio.

Mesmo sendo falso, tanto Poluído quanto a sua mulher acreditavam estar divorciados. A confusão só foi desfeita quando o Jeca vai procurar a fazendeira para tentar reaver os papeis e anular o divórcio. No entanto, quando chega à residência de Dionísia ouve a conversa da proprietária com o seu advogado, em que ambos riem por terem enganado toda a cidade, e afirmam que a lei ainda não foi aprovada. A fazendeira afirma ainda que foi ela quem matou o Camarão, e fez isso porque descobriu que a vítima planejava liquidá-la. Ao ouvir toda a confissão dos vilões, Poluído se dirige à delegacia para informar ao delegado a descoberta.

Essas análises são interessantes à medida que fortalecem o enredo e abordam questões importantes de forma suave e eufêmica, garantindo leveza à mensagem levada ao público, mesmo quando abordam temas como violência e desigualdade, representados pelas crueldades de Dionísia e do advogado quando usa o seu conhecimento e informação para trapacear.

Outra questão interessante do filme é a passagem de Jesus Cristo. A primeira cena em que Poluído aparece conversando com Jesus acontece quando o Jeca está desanimado com as injustiças do mundo. Seu filho estava preso, o mundo se modernizando, sentia que não pertencia mais àquele lugar. Ele passa então a questionar o motivo de existir tanta gente que faz o mal, mas que tem

5 Lembrando que Dionísia deriva do Deus grego Dionísio, conhecido como Deus da insânia e da intoxicação. 
bastante dinheiro e tanta gente que só faz o bem e não tem quase nada. Assim argumenta que dinheiro não traz felicidade e que a maior riqueza é ser feliz.

O interessante é que no final do filme o público descobre que Jesus Cristo na verdade era um hippie. Essa descoberta causa certa curiosidade, pois não fica definida a intenção de Mazzaropi ao criar aquele personagem, podendo levar a várias interpretações, mas o fato é que o diálogo retoma a discussão sobre desigualdade econômica e injustiça social, e de certo modo não deixa de ser representada durante todo o filme. Porém, essas questões reforçam a necessidade de entender essa analogia a Cristo, talvez por contrapor o Capeta ou então para mostrar um novo grupo social que se formava nos anos de 1970, os hippies ${ }^{6}$.

Por fim, o último aspecto que proponho analisar é a sátira a um dos filmes hollywoodianos de maior sucesso nos anos de 1970 - O exorcista. Mazzaropi não propôs a reprodução do enredo do filme, pelo contrário. Como vimos, a história é marcada por grandes acontecimentos norteados por um assunto muito distante do filme norte-americano - que é o tema do divórcio. Nesse sentido, o produtor demonstra de forma alusiva e lúdica que tais manifestações sobrenaturais podem muito bem ser explicadas no mundo dos homens. O medo das pessoas é que faz com que elas acreditem no fenômeno de incorporação do demônio. Poluído inclusive chega a acreditar que sua esposa está com o demônio no corpo, do mesmo modo que a menina do filme "O eletricista". Contudo, no final, mais uma vez a crença em poderes sobrenaturais é desfeita quando descobrem que a cama em que Poluído estava se mexia devido aos cachorros que estavam debaixo do móvel.

O que se pode entender dessa sátira, principalmente pela alusão aos fenômenos sobrenaturais, sendo explicados por fatores concretos, é que Mazzaropi pretendia mostrar, com este filme, que não era preciso priorizar filmes estrangeiros para atingir o grande público, visto que o cinema nacional era capaz de produzir filmes lucrativos. Além disso, o produtor mostrou que conseguia lotar as salas de cinema com filmes simples, que abordavam de forma cômica e leve assuntos do próprio cotidiano da população do interior. Essa hipótese pode ser levantada a partir do depoimento que Mazzaropi concedeu ao jornalista Caco Barcelos no dia 5 de abril de 1976.

Muita gente faz cinema no Brasil para consumo próprio e não percebe que não faz sucesso porque vive divorciada do povo, falam uma linguagem intelectual e o povo não gosta de pensar. Analisem bem o Tubarão, os

\footnotetext{
Em nenhuma das críticas sobre o filme encontrei uma explicação sobre o personagem de Cristo. Zulmira Tavares defende que era um símbolo representativo que foi explicado no mundo dos homens.

7 Termo pelo qual o personagem de Mazzaropi, Poluído, refere-se ao filme O exorcista. Este recurso garante a comicidade da cena.
} 
americanos fazem e levam o dinheiro daqui. Me dá uma vontade de dar um soco nos beiços daquele bonecão quando ele aparece com aqueles dentão na tela. Porque nós não fizemos para o dinheiro ficar aqui mesmo (MAZZAROPI, 1976).

Considerando a mesma lógica do filme Tubarão (1975) para O exorcista (1973), o que Mazzaropi critica é a falta de investimento no cinema nacional. Quando ele indaga o motivo de nenhum cineasta brasileiro ter feito o filme antes de Hollywood, mostra todo o seu ressentimento. E argumenta que se o filme tivesse sido produzido no Brasil, o sucesso e os lucros poderiam fomentar a indústria cinematográfica nacional e não aumentar os lucros estrangeiros.

Ainda neste depoimento, Mazzaropi comenta o sucesso do filme de 1975:

Então eu fiz este ano o Jeca Contra o Capeta achando que nunca mais atingiria rendas tão altas como as outras. Mas tive outra agradável surpresa: um milhão de pessoas já viram a fita que está na quinta semana do circuito Serrador em São Paulo. É uma barbaridade (MAZZAROPI, 1976).

O seu discurso não muda. O sucesso de seus filmes é constantemente comparado com os filmes estrangeiros, sendo que alguns deles perdem espaço para a exibição dos filmes do Jeca.

O depoimento "Jeca contra o tubarão" é ainda mais interessante quando se analisam os depoimentos de pessoas comuns que assistem aos filmes do Mazzaropi, principalmente da cidade de São Paulo. O próprio produtor defende que a capital paulista é um lugar de caipiras, chegando a caracterizar a variedade que existe na cidade. Em um trecho Mazzaropi defende a sua posição no sentido de produzir filmes de acordo com o que o público caipira deseja encontrar no cinema.

Sempre me preocupei com o caboclo, o caipira, que foi mudando seu temperamento, na medida em que a sociedade entrava na onda do desenvolvimento. Antigamente eu contava uma história ingênua e todos gostavam. Eu dizia que queria casar com uma namorada mas o pai dela não queria deixar. Depois eu falava que ia dar um tiro no meu ouvido e outro no dela, para nós dois juntinhos nos unirmos no céu e era o maior sucesso. Hoje o povo dá gaitada disto, acha ridículo. Eles estão com a TV em casa e não querem mais saber de riscar o dedão no chão como faziam antes (MAZZAROPI, 1976).

Essa consciência da importância do seu público é a grande defesa do produtor, principalmente ao rebater as críticas sobre a falta de qualidade do seu trabalho. Segundo ele, qualquer enredo que for criado respeitando a opinião e a vontade do público tende ao sucesso. Para argumentar essa questão, cita trabalhos anteriores, como Portugal, minha saudade (1973), que foi um "drama 
desgraçado", como ele mesmo relata, mas que atingiu sucesso de público. Para Mazzaropi, o público vai aplaudir tanto o filme que lhe faz rir quanto os que lhe faz chorar, mas que, no entanto, seja condizente com a realidade e possibilidades de compreensão dos espectadores.

A escolha do filme de 1975 para analisar o sucesso de Mazzaropi como produtor cinematográfico não foi aleatória, visto que foi o que atingiu ${ }^{8}$ a maior bilheteria de sua carreira, superando inclusive filmes estrangeiros. Sobre isso, o produtor defende que:

[...] enquanto o Jeca briga com o diabo nas telas dos cinemas paulistas, Charles Bronson e outras fitas estrangeiras terão que esperar a vez com muita "humildade", diz Mazzaropi sorridente e às vezes debochado: "porque eu mesmo não esperava tanto sucesso com O Jeca contra o Capeta (MAZZAROPI, 1976)'.

Nos depoimentos e entrevistas Mazzaropi não esconde a alegria de superar as fitas estrangeiras em número de público. Como já mostrado, sua intenção era criar uma indústria cinematográfica brasileira. Para ele, "enquanto o país continuaar abrindo espaço para os filmes estrangeiros, terá menos chance de investir em produções próprias". A própria independência de Mazzaropi em relação à sua produção é prova desse contexto. $\mathrm{O}$ fato de utilizar recursos financeiros próprios na realização de um filme mostra a dificuldade de receber incentivo externo. $\mathrm{O}$ fator positivo é que a renda própria, além de ser suficiente para os gastos com a produção de um longa-metragem, ainda garante a manutenção e aquisição de equipamentos cinematográficos mais modernos.

Neste sentido, o fato de o título do depoimento de Mazzaropi a Caco Barcelos ter sido "Jeca contra o tubarão" define exatamente essa problemática que o produtor tanto defendia. Além de ser contra a abertura que o Brasil dava à exibição de filmes norte-americanos, não via nas produções nacionais um estímulo à produção de filmes de sucesso, pois, em sua opinião, muitos intelectuais se preocupavam mais em produzir filmes que rompessem paradigmas do que se atentar para a vontade do público consumidor.

8 Cr\$15.258.957,70. Espectadores: 2.602.630. Mês de lançamento: fevereiro. Figura em $2^{\circ}$ lugar na lista: das "10 maiores rendas do filme nacional em 1976". Figura em $2^{\circ}$ lugar na lista das "10 maiores rendas do filme nacional no período de 6 anos" “(de julho de 1970 a dezembro de 1976)". Figura em $5^{\circ}$ lugar na lista das " 10 maiores rendas do filme nacional no período de julho de 1970 a junho de 1977, com a renda de Cr\$16.268.307,40; e com 2.786.165 espectadores". Disponível em: <http://www.cinemateca.gov.br/cgi- bin/wxis.exe/iah/?IsisScript=iah/iah.xi s\&base $=$ FILMOGRAFIA\&lang $=$ p\&nextAction $=\operatorname{lnk} \&$ exprSearch $=I D=023417 \&$ format $=$ det ailed.pft\#1.

9 Ver o depoimento “O Jeca contra o tubarão". 


\section{MAZZAROPI E A CRÍTICA AO CINEMA NOVO}

Em 1970, Mazzaropi concedeu uma entrevista à revista Veja, na qual ele analisa o panorama do cinema nacional. Essa entrevista é importante, na medida em que ele fala do seu sucesso com o público, da sua visão sobre o cinema como indústria e critica as produções do Cinema Novo (SIMONARD, 2006). A entrevista "O Brasil é meu público", que foi concedida ao jornalista Armando Salem em 28 de janeiro de 1970, será a fonte utilizada para estabelecer a relação entre Mazzaropi e o Cinema Novo.

Para entender a crítica de Mazzaropi é preciso antes entender o surgimento do Cinema Novo e sua proposta. Segundo o artigo de Armando Salem, a proposta era criar um estilo próprio de fazer cinema no Brasil, e não reproduzir o modo de vida norte-americano, que era difundido principalmente através dos filmes de Hollywood. Era necessário criar uma identidade nacional. Por isso, era muito comum a produção de filmes que retratassem o subdesenvolvimento do país, que denunciasse questões sociais. Além disso, não reconheciam que havia uma produção de filmes nacionais, a não ser pela produtora Vera Cruz e pelos filmes de chanchadas ${ }^{10}$ dos anos de 1930 e 1940.

Os filmes de chanchadas deixaram de fazer sucesso no final dos anos de 1950 porque não acompanharam a mudança pela qual a população brasileira passara nesses anos. Na cena paulista, a companhia Vera Cruz, fundada em 1949, tinha a proposta de criar uma indústria cinematográfica nacional que produzisse filmes de qualidade. Para isso, seus criadores não pouparam recursos para contratar profissionais estrangeiros e equipamentos de alta qualidade. O problema é que tais investimentos foram maiores que a renda de seus filmes, fazendo com que a produtora entrasse em crise financeira, vindo a falir poucos anos depois.

Segundo Ramos (1987), a produtora Vera Cruz também não obtinha o retorno financeiro porque:

[...] a empresa preocupava-se apenas com a produção, deixando a distribuição a cargo de multinacionais também produtoras de filmes e que não tinham interesse nenhum em ceder um pedaço do seu mercado para o cinema brasileiro (RAMOS, 1987). Nesse sentido, o Cinema Novo aparece como uma forma de se diferenciar das experiências anteriores e propor a produção de filmes baratos e condizentes com a realidade de um país em desenvolvimento. Seus idealizadores defendiam que um filme de qualidade pode ser feito com apenas uma câmera na mão e uma ideia na cabeça.

10 Gênero fílmico que mistura enredo carnavalesco com cenas de ação, canção e muita comédia. Nos anos de 1940 ficou conhecido por retratar na maioria dos filmes o típico malandro carioca e suas peripécias. 
Mazzaropi acompanhara todo esse processo, inclusive chegou a trabalhar na produtora Vera Cruz, onde produziu três filmes. Sabia dos problemas da produtora passava e, em certa medida, o que causara esses problemas. Um deles evidentemente era a distribuição, tanto que, logo após a criação de sua produtora, Mazzaropi tratou logo de criar uma distribuidora para impedir os desvios financeiros, além de contratar fiscais para evitar fraudes nas salas de exibição. Muito do sucesso do cineasta deveu-se aos seus cuidados desde o processo de produção até a exibição de um filme.

Observando o quadro cinematográfico no Brasil, Mazzaropi fazia muitas críticas em relação ao Cinema Novo. Observava que as produções neste gênero não atingem o grande público. Segundo ele, isso era prejudicial, na medida em que, diferentemente dos filmes produzidos pela PAM- filmes, não ajudam a indústria de cinema no Brasil.

Não posso falar pelos outros porque não conheço os resultados dos números daquilo que eles fazem. Tenho muita vaidade em dizer que eu não tenho nenhum problema de exibição de meus filmes. Os exibidores fazem fila na porta da Pam-Filmes. O público vai ver minhas fitas e sai satisfeito. Eu já consegui colocar 13.000 pessoas num dia, nas várias sessões do Art Palácio, em São Paulo. Com isso, ando de cabeça erguida. Agora, pelo outro tipo de filme feito no Brasil, não respondo. Não sei se ele pode ajudar a indústria cinematográfica nacional (MAZZAROPI, 1976).

Ainda sobre o Cinema Novo, caracteriza-o como estilo feito para uma minoria de intelectuais.

Não, eu não tenho nada contra ele. Só acho que a gente tem que se decidir: ou faz fita para agradar os intelectuais (uma minoria que não lota uma fileira de poltronas de cinema) ou faz para o público que vai ao cinema em busca de emoções diferentes. O público é simples, ele quer rir, chorar, viver minutos de suspense. Não adianta tentar dar a ele um punhado de absurdos: no lugar da boca põe o olho, no lugar do olho põe a boca. Isso é para agradar intelectual (MAZZAROPI, 1976).

O ressentimento de Mazzaropi está no fato de os intelectuais reconhecerem a qualidade dos filmes do Cinema Novo, mas não a dos seus. Para o produtor, o cinema nacional só se transformará em indústria quando os espectadores brasileiros deixarem de lotar os cinemas para assistirem filmes estrangeiros e passarem a assistir filmes nacionais, e que isso só será possível quando os filmes atenderem às exigências do público, que, no final, torna-se o principal crítico, à medida que determina ou não o sucesso de um filme. 


\section{CONSIDERAÇÕES FINAIS}

É válido ressaltar que a proposta deste trabalho não é desqualificar a produção do Cinema Novo, pelo contrário. Reconhecemos que o momento político no qual esses filmes eram produzidos dificultava muito a divulgação dos mesmos, fator que pode explicar a falta de público. Censura, falta de investimento e recursos são temas importantes que estão além das margens desse artigo, mas são de fundamental importância para estudos sobre a cinematografia brasileira. A intenção deste trabalho, portanto, foi reabilitar a produção de Mazzaropi através do resgate da visão do cineasta sobre o cinema brasileiro, pois, antes de ser um empresário que visava ganhar muito por dinheiro, ele era um produtor que tinha um sonho.

Mazzaropi defendia que o seu sucesso e o seu dinheiro eram resultados do diálogo que seus filmes sempre mantiveram com o público. Ele não via cinema apenas como arte, mas também como um negócio. Nas entrevistas analisadas foi possível perceber que seus planos e desejos eram os mesmos: continuar fazendo de seu negócio a arte de entreter o púbico.

\section{REFERÊNCIAS}

ARAÚJO, I. 'O Corintiano' é uma das grandes comédias feitas por Mazzaropi”. Folha de São Paulo,São Paulo, 6 jun. 2013.

ARAUJO, I. De lucro certo, filmes do comediante tinham encontro marcadocom público.”. Folha de São Paulo,São Paulo,3 abr. 2012.

BARCELOS, C. Jeca contra o tubarão. Jornal Movimento,São Paulo, 5 de abril de 1976.

BARSALINI, G. Mazzaropi:o Jeca do Brasil. São Paulo: Átomo, 2002.

BOURDIEU, P. Coisas Ditas. Tradução de Cássia R. da Silveira e Denise Moreno Pegorim. São Paulo:Brasiliense, 1994.

BRAGANÇA, M. “Jeca Tatu por Mazzaropi”. Ipotesi, Juiz de Fora, v. 13, n. 1, p. 103 116, jan./jul. 2009.

CANDIDO, A. Os parceiros do Rio Bonito. São Paulo: Duas Cidades; Ed. 34, 2001.

FASSONI, O.Sai de baixo, Mazzaropi. Folha de São Paulo,São Paulo,8 jun. 1977.

FERRO, M. Cinema e História.Tradução deFlávia Nascimento. Rio de Janeiro: Paz e Terra, 1992.

FONSECA, Rodrigo. Documentário mostra importância de Mazzaropi. O Globo, Rio de Janeiro, 4 fev. 2013.

FRESSATO, S. B. Caipira sim, trouxa não:representações da cultura popular no cinema de Mazzaropi. Salvador: EDUFBA, 2011.

GOFF LE, J.;NORA, P. História:novos objetos. São Paulo: Francisco Alves, 1976.

Novos Cadernos NAEA •v. 18 n. 3 • p. 293-307• set-dez. 2015 
LEAL, V. N. Coronelismo, enxada e voto. São Paulo: Alfa-Omega, 1986.

LIMA, N. T. Um sertão chamado Brasil. Rio de Janeiro: Revan, 1998.

LOYOLA, I. A Contribuição de Mazzaropi para o Retrocesso.Última Hora,São Paulo, 4fev. 1965. Cine-Ronda.

MARTINELLI, S. Vera Cruz: imagens e história do cinema brasileiro. São Paulo: Abooks, 2002.

MATOS, M. Sai da frente! A vida e Obra de Mazzaropi. Rio de Janeiro: Desiderata, 2010.

MAZZAROPI. 1976. Entrevista concedida a BARCELOS, C. Jeca contra o tubarão. Jornal Movimento, 5 de abril de 1976.

MAZZAROPI. 1970. Entrevista concedida a SALEM, A. O Brasil é meu público. Revista Veja, 28 de janeiro de 1970.

MELLO,C. Narrativas de Paulicéia: caipiras numa cidade em transformação. Fênix Revista de História e Estudos Culturais. v. 6, n. 1, jan.-mar. 2009.

MENDONÇA, S. R. As bases do desenvolvimento capitalista dependente: da industrialização restringida à internacionalização. In: LINHARES, M. Y. (Org). História geral do Brasil. Rio de Janeiro: Campus, 1998. p. 267-299.

MOREIRA, P. L. A Hollywood caipira. Folha de São Paulo,São Paulo,8 jun. 1977.

MOREIRA, V. JK: industrialização e modelo oligárquico de desenvolvimento. In:

NÓVOA, J.; FRESSATO, S. B.; FEIGELSON, K. (Org.). Cinematógrafo - um olhar sobre a história. Salvador:EDUFBA; São Paulo: EDUNESP, 2009.

ORTIZ, R.A moderna tradição brasileira. São Paulo: Brasiliense, 1991.

PAM-FILMES. O jeca contra o capeta. Direção: Pio Zamuner e AmácioMazzaropi. Intérpretes: Mazzaropi; Geny Prado; Roberto Pirilo; Néa Simões; Fausto Rocha Jr; Rose Garcia; Jair Talarico e outros. Distribuição: PAM - filmes (SP). Duração: 105min. São Paulo: PAM-Filmes, 1975.

RAMOS, F. (Org.). História do Cinema Brasileiro. São Paulo: Art, 1987.

RODRIGUES, C. R.; SOUZA, O. R. N. Mazzaropi:a imagem de um caipira. São Paulo: Serviço Social do Comércio; Taubaté: Universidade de Taubaté/Centro de Documentação e Pesquisa Histórica, 1994.

RODRIGUES, M. O Brasil na década de 1950. 3. ed. São Paulo: Memórias, 2010.

SALEM, A. O Brasil é meu público. Revista Veja,São Paulo, 28 de janeiro de 1970.

SILVA, F. (Org.). História e imagem. Rio de Janeiro: UFRJ, 1998.

SIMONARD, P. A geração do Cinema Novo:para uma antropologia do cinema. Rio de Janeiro: Mauad, 2006.

TAVARES, Z. De pernas pro ar. Jornal Movimento, 5 abr. 1976.

TOLENTINO, C. O rural no cinema brasileiro. São Paulo: EDUNESP, 2001.

Texto submetido à Revista em 13.01.2015

Aceito para publicação em 05.08.2015 
